\title{
Coagulation Abnormalities Due to COVID-19 in a Child with Thalassemia: Authors' Reply
}

\author{
Wulandewi Marhaeni ${ }^{1} \cdot$ Andreas Budi Wijaya $^{2}$
}

Received: 29 April 2021 / Accepted: 17 May 2021 / Published online: 7 June 2021

(C) Dr. K C Chaudhuri Foundation 2021

To the Editor: We thank Rujittika Mngmunpuntipantip and Viroj Wiwanitkit for sharing ideas related to our study on coagulation abnormalities due to COVID-19 in betathalassemia children, an issue of current public health importance [1]. In our study, the thalassemia patients had no other congenital hematological disorder comorbidities, especially sickle cell anemia or G-6-PD deficiency [2]. We have screened all of our patients for G-6-PD deficiency possibilities in the initial diagnosis. Pathological problem such vasoocclusive crises (VOC) might be promoted in individual with both thalassemia and sickle cell disease, especially in alphathalassemia population [3]. However, there was no adequate evidence about the occurrence of VOC in beta-thalassemia alone, without sickle cell disease [4]. Abnormal coagulation disorder might also be related to liver-function impairment due to complication of thalassemia itself or as adverse effect of iron chelation use [5, 6]. Based on previous regular laboratory examination, all of included patients in the study had normal liver function without history of hepatitis. After getting infected with COVID-19, 2 of the 4 patients with thalassemia had slight increase in aspartate transaminase enzyme, but not more than 2 times the upper limit. We agree with the authors regarding the importance of excluding other possible confounding pathology that might result in abnormal coagulation profile, especially in SARS-Cov-2 infection associated with transfusion-dependent-thalassemia.
Wulandewi Marhaeni

wdmarhaeni@yahoo.com

1 Hematology-Oncology Division, Department of Pediatrics of Ulin General Hospital, Faculty of Medicine, Lambung Mangkurat University, Banjarmasin, South Kalimantan 70123, Indonesia

2 Department of Pediatrics of Ulin General Hospital, Faculty of Medicine, Lambung Mangkurat University, Banjarmasin, South Kalimantan, Indonesia

\section{Declarations}

Conflict of Interest None.

\section{References}

1. Coagulation Abnormalities Due to COVID-19 in a Child with Thalassemia: Correspondence. Indian J Pediatr. 2021. https://doi. org/10.1007/s12098-021-03811-8.

2. Marhaeni W, Wijaya B. Khairiyadi, Munawaroh, Hendriyono. Coagulation abnormalities due to COVID-19 in a child with thalassemia. Indian J Pediatr. 2021;88:396-7.

3. Renoux C, Connes P, Nader E, et al. Alpha-thalassaemia promotes frequent vaso-occlusive crises in children with sickle cell anaemia through haemorheological changes. Pediatr Blood Cancer. 2017;64. https://doi.org/10.1002/pbc.26455.

4. Vilela TD, Braga AP, Loggetto SR. Hemoglobinopathy and paediatrics in the time of COVID-19. Hematol Transfus Cell Ther. 2021;43:87-100.

5. Abosdera MM, Almasry AE, Abdel-Moneim ES. Coagulation defects in thalassemic patients. Pediatr Neonatol. 2017;58:421-4.

6. Angchaisuksiri P, Atichartakarn V, Aryurachai K, et al. Hemostatic and thrombotic markers in patients with hemoglobin E/Bthalassemia disease. Am J Hematol. 2007;82:1001-4.

Publisher's Note Springer Nature remains neutral with regard to jurisdictional claims in published maps and institutional affiliations. 